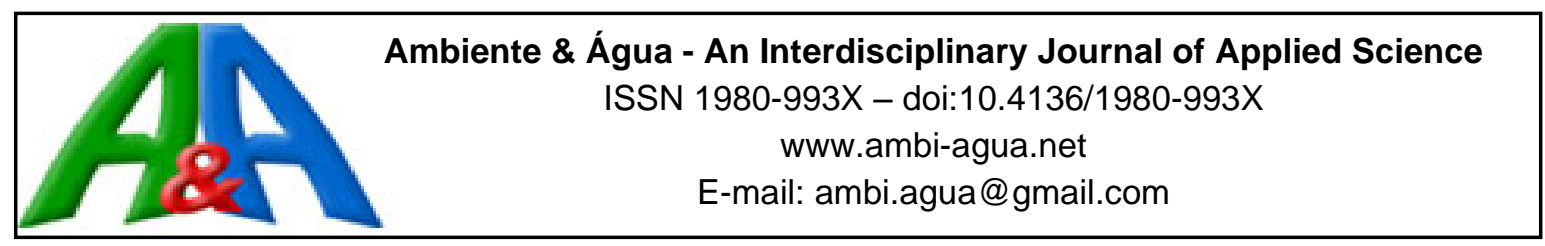

\title{
Nanosatellites applied to optical Earth observation: a review
}

\author{
ARTICLES doi:10.4136/ambi-agua.2513
}

Received: 20 Dec. 2019; Accepted: 08 May 2020

\author{
Gustavo Willy Nagel*iD; Evlyn Márcia Leão de Moraes Novo ${ }^{\circledR}$; Milton Kampel \\ Coordenação-Geral de Observação da Terra. Divisão de Sensoriamento Remoto. Instituto Nacional de Pesquisas \\ Espaciais (INPE), Avenida dos Astronautas, n 1758, CEP: 12227-010, São José dos Campos, SP, Brazil. \\ E-mail: evlyn.novo@inpe.br, milton.kampel@inpe.br \\ *Corresponding author. E-mail: gustavo.nagel@inpe.br
}

\begin{abstract}
Nanosatellites and CubeSats were first developed for educational purposes. However, their low cost and short development cycle made nanosatellite constellations an affordable option for observing the Earth by remote sensing, increasing the frequency of high-resolution imagery, which is fundamental for studying and monitoring dynamic processes. In this sense, although still incipient, nanosatellite applications and proposed Earth observation missions are steadily growing in number and scientific fields. There are several initiatives from universities, space agencies and private companies to launch new nanosatellite missions. These initiatives are actively investigating new technologies to improve image quality and studying ways to increase acquisition frequency through the launch of larger constellations. So far, the private sector is leading the development of new missions, with proposals ranging from 12 to more than one thousand nanosatellite constellations. Furthermore, new nanosatellite missions have been proposed to tackle specific applications, such as natural disasters, or to test improvements on nanosatellite spatial, temporal and radiometric resolution. The unprecedented combination of high spatial and temporal resolution from nanosatellite constellations associated with improvement efforts in sensor quality is promising and may represent a trend to replace the era of large satellites for smaller and cheaper nanosatellites. This article first reports on the development and new nanosatellite missions of space agencies, universities and private companies. Then a systematic review of published articles using the most successful private constellation (PlanetScope and Doves) is presented and the principal papers are discussed.
\end{abstract}

Keywords: cubeSat, planetScope, remote sensing.

\section{Nanossatélites aplicados à observação da Terra ótica: uma revisão}

\section{RESUMO}

Os nanossatélites e os CubeSats foram desenvolvidos pela primeira vez para fins educacionais. No entanto, seu baixo custo e curto ciclo de desenvolvimento fizeram com que constelações de nanossatélites se tornassem uma opção acessível para aumentar a frequência de imagens de alta resolução visando o sensoriamento remoto de observação da Terra, requisito fundamental para o estudo e monitoramento de processos dinâmicos. Nesse sentido, embora ainda incipientes, as aplicações de nanossatélites e as missões propostas estão crescendo constantemente em número com aplicações em diferentes campos científicos. Existem várias iniciativas de universidades, agências espaciais e empresas privadas para lançar novas missões

This is an Open Access article distributed under the terms of the Creative Commons Attribution License, which permits unrestricted use, distribution, and reproduction in any medium, provided the original work is properly cited. 
de nanossatélites. Essas iniciativas vêm investigando novas tecnologias para melhorar a qualidade das imagens e vêm estudando maneiras de aumentar a frequência de aquisição através do lançamento de grandes constelações de nanossatélites. Até agora, o setor privado está liderando o desenvolvimento de novas missões, cujas propostas envolvem a criação de constelações cujo número varia de 12 a mais de mil nanossatélites. Além disso, novas missões de nanossatélites vem sendo propostas para lidar com aplicações específicas, como desastres naturais, ou para testar melhorias na resolução espacial, temporal e radiométrica de nanossatélites. A combinação, sem precedentes, de alta resolução espacial e temporal oferecida pelas constelações de nanossatélites, associada a esforços de melhoria na qualidade do sensor é promissora e pode representar uma tendência das agências espaciais, universidades e empresas privadas de substituição de grandes satélites por nanossatélites menores e mais baratos. Este artigo relata primeiramente o desenvolvimento e novas missões de nanossatélites. Em seguida, uma sistemática revisão de artigos publicados usando a constelação de maior sucesso (PlanetScope e Doves) é apresentada e os principais trabalhos discutidos.

Palavras-chave: cubeSat, planetScope, sensoriamento remoto.

\section{INTRODUCTION}

Earth observation using orbital platforms has become an important and effective tool for promoting sustainable development by assessing historical trends on Earth's surface changes and their spatial correlation (Sandau et al., 2010). In this context, there are several satellite systems with different characteristics, with a wide range of different radiometric, spectral, spatial and temporal sensor's resolutions. Due to the lower development costs, nanosatellites (mass between $1-10 \mathrm{Kg}$ ) have been launched in great numbers, promoting an unprecedented combination of high temporal and spatial resolution. These groups of satellites orbiting the Earth are called "constellations", and provide frequent information on the Earth's surface, which is useful to monitor the fast pace of anthropogenic and climate-change impacts, such as frequent forest fires (Flannigan et al., 2000; 2006; Gillet et al., 2004), increased rates of melting ice, damage caused by natural disasters, frequent harmful algal blooms, and food production losses (Deutsch et al., 2018; Paterson et al., 2010; Zhang and Liu, 2005), among others.

The last decade of the $20^{\text {th }}$ century was a turning point in the space development trend. CubeSats standard $(10 \mathrm{~cm} \times 10 \mathrm{~cm} \times 10 \mathrm{~cm}$ format $)$, a type of nanosatellite opened a new cycle of space mission development related to their flexibility and success rate, with affordable mission failures related to the low launching costs (Shiroma et al., 2011). CubeSats might be $1 \mathrm{U}$, with the most-used being the $3 \mathrm{U}(10 \times 10 \times 30 \mathrm{~cm}), 4 \mathrm{U}$, and other formats according to the mission's requirements (Shiroma et al., 2011; Villela et al., 2019). Recent advances in microelectronics and microsystems introduced lighter components reducing energy consumption, size and mass, which increased the satellite design flexibility (Davoli et al., 2018). Nanosatellites' lower costs (around 1 million dollars) contrasts with the investment of traditional large satellites, such as Landsat and Sentinel, which cost around 855 and 300 million dollars, respectively (Landsat Advisory Group, 2018). Moreover, CubeSats are launched as a secondary payload, taking advantage of the large satellite launches, reducing mission costs even further (Swartwout, 2013).

This cost reduction allowed universities, private companies and countries outside the mainstream space agencies to invest and implement space missions, which otherwise would be too costly to afford (Villela et al., 2019). This has led to space democratization, bringing new cycles of space technology development by engaging more people and different cultures. However, it is the private sector that has been leading the development of nanosatellites. The company Planet has, so far, used the CubeSat advantages to launch the most successful CubeSat 
constellation, with 120 PlanetScope satellites that offer, on a global scale, a pioneering combination of high spatial and temporal resolution (Cooley et al., 2017).

So far, the nanosatellite Earth observation applications use mainly PlanetScope images. Studies that require high detail and frequent images to study dynamic land cover, oceanography, vegetation, and inland water have been done using the PlanetScope constellation. However, new nanosatellite proposals and technological demonstrations from universities, space agencies and especially other private companies might challenge the current Planet Company market domination. Companies such as SatRevolution, for example, aim to launch more than one thousand nanosatellites to obtain minute-level Earth observation, a huge amount of information that will require new ways of storage and data processing. Furthermore, highly specialized nanosatellites have been proposed to observe specific processes, such as natural disasters, inland water resources and rates of ice melting.

This article first reports on the development of nanosatellite constellations from space agencies, universities and private companies. Additionally, a systematic review is carried out to identify remote-sensing articles published in international remote-sensing journals, which discuss the PlanetScope or Doves constellations. In the same sector, key articles in areas of vegetation, natural disaster, oceanography and inland water were selected for discussion. Furthermore, based on the articles reviewed, the principal limitations of nanosatellites were identified.

\section{NANOSATELLITES SPACE MISSIONS}

This section describes the planning of different sectors of nanosatellite optical Earth observation missions. First, the development of nanosatellite is described by space agencies from both developed and developing countries. Then a survey of nanosatellite constellations proposed by the private sectors of different countries is presented. For this analysis, only companies with proposed nanosatellite information on their webpages were included.

Traditional space agencies have been investing in nanosatellites in order to support universities, to test new technologies and as a complement to their large-satellite data. The main agency supporting the development of nanosatellites is the National Aeronautics and Space Administration (NASA), with an educational program ElaNa (Educational Launch of Nanosatellites), started in 2010, which aimed to attract students to technological careers (Crusan and Galica, 2016). Since the beginning of the program, 85 CubeSats have been developed through 25 ElaNa calls, with a provision of more 35 CubeSats in more than 4 calls (Camps, 2019). These projects have given NASA expertise in testing emerging technologies to be used in future CubeSat missions. NASA is also developing its own CubeSats, such as the $1 \mathrm{U}$ CubeSat Intelligent Payload Experiment (IPEX), in partnership with California Polytechnic State University, to validate a system to reduce data volume by twenty times in cases of urgent imageproduct generation (Jet Propulsion Laboratory, 2019).

The ESA (European Space Agency) is also increasingly recognizing the potential of nanosatellites. Piro et al. (2018), for instance, proposed a $3 \mathrm{U}$ hyperspectral CubeSat, the Hyperspectral Bridge for Sentinels (HYBRIS) to the ESA as a component of the Copernicus constellation. Sensor design specifies 270 bands distributed between $400 \mathrm{~nm}$ to $1000 \mathrm{~nm}$ with $6 \mathrm{~nm}$ spectral resolution (Piro et al., 2018). According to the authors, such a sensor would be useful for studying atmospheric composition, open oceans, coastal regions, continental waters, agriculture, forest, land-cover changes and geology (Piro et al., 2018). However, the ESA is planning to support the Copernicus program with a 6U CubeSat called FSSCat to be launched in 2020 (Copernicus Masters, 2017). The FSSCat payload will include a microwave and a multispectral optical sensor with a $40 \mathrm{~m}$ spatial resolution focused on polar regions (soil moisture, ice extent, ice thickness, melting ponds over ice) (Copernicus Masters, 2017). The ESA argues that the FSSCat would be the precursor of a larger CubeSat constellation, able to 
offer high temporal resolution at moderate spatial resolution (Copernicus Masters, 2017).

Nevertheless, other countries not traditionally active in space technology are also investing in nanosatellites. Earth observation nanosatellites, for instance, have been developed in African countries (Woldai, 2020), including the XinaBox ThinSat (planned to launch in 2020 by South Africa, AngoSat-1 and 2, ALSAT-1N (Algerian Space Agency), the Egyptians NileSat-201, NileSat-301, NExSat-1 (planned to be launched in 2019 but delayed) and NARSSCube-2 (identical to NARSSCube-1). Furthermore, Ghana, Kenya, Morocco, Rwanda, Sudan, and Ethiopia are all investing in low-cost nanosatellites (Woldai, 2020). According to Xue et al. (2008), space agencies from Germany, Italy, Sweden, Argentina, Spain, Thailand, Pakistan, Turkey, Japan, South Korea, India, and China are all developing their CubeSats, a considerable expansion in the spatial industry.

The simple architecture, and reduced development and launch costs made the concept of nanosatellite constellations possible. Moreover, the need for smaller capital for launching allowed the engagement of private companies and universities in space missions, something unthinkable at the beginning of the space era. Statistics regarding nanosatellite launch success (Villela et al., 2019) follows a binomial distribution, with the probability increasing from around 30\% in 2003 to nearly $75 \%$ in 2018. However, space agencies and universities have developed and launched CubeSats in small numbers, normally for technological demonstrations or educational purposes. With the launch of single units, for example, the Aalto University (Finland) developed a nanosatellite called Aalto-1, a 3U CubeSat for Earth observation (ESA, 2020); the University of Nairobi (Kenya) developed a nanosatellite 1 U called 1KUNS-PF (Nanosats and Cubesats Database) and Wuhan University (China) developed the Luojia 1-01, a 6U CubeSat for Night-light Earth observation (in the future is planned to launch a constellation of 60-80 Luojia 1-01) (Nanosats and Cubesats Database).

In contrast, the private sector is leading the development of new CubeSats, attempting to launch constellations of hundreds or even thousand satellites that offer daily coverage images (expecting to be minute-level coverage in the future), an advantage that is challenging the traditional large satellites. These companies normally contract satellite manufacturing and launch from other private companies, creating a global chain of space services and products (Rabionet, 2019). The company Surrey Satellite Technology, for example, offers a 12U CubeSat platform to customers who want to launch payloads to earth observation, technology demonstration, radiation monitoring, among others (Surrey, 2019).

Considering the lower costs of nanosatellites, even traditionally non-space countries are developing CubeSats in the private sector. Portugal aims to launch its first satellite through the TEKEVER company, the 16U CubeSat called INFANTE (Tekever, 2019). However, most of the private progress is still concentrated in countries with more developed spatial industries, such as the USA, China or Europe. The American company Astro Digital has launched 6 nanosatellites 6U (Astro Digital's Corvus Platform) into orbit, which have a $22 \mathrm{~m}$ spatial resolution in RGB and NIR bands (Astro Digital, 2018) since 2017. Similarly, Karten Space, a Spanish company, is developing a constellation of 6U CubeSats (Karten Space Earth Observation Satellites), with four bands (RGB and NIR), $3 \mathrm{~m}$ spatial resolution and daily coverage (Karten, 2019). Another Spanish company, Aistech Space, is also planning a 150nanosatellite constellation to be launched until 2022 (Aistech Space, 2019). Reaktor Space, based in Finland, has launched in 2018 the smallest hyperspectral imager, the Reaktor Hello World, a 2U CubeSat with 100 bands (900-1400 nm) and $22 \mathrm{~m}$ spatial resolution designed for agricultural applications (Reaktor Space Lab, 2019).

With higher ambitions, the company SatRevolution aims to launch a Real-Time Earth Observation Constellation (REC), which will consist of 1024 6U CubeSats to be launched until 2026. With $50 \mathrm{~cm}$ spatial resolution, the satellites will be divided between Type I, with four bands (RGB and NIR), Type II, with 32 bands and Type III, with 600 bands. Considering the 
number of CubeSats in orbit, the company estimates that the revisit time will reach $30 \mathrm{~min}$ (Satrevolution, 2019), an unprecedented high temporal resolution. The company, which operates in the USA and Poland, has the European Union as an investor.

As China's government invests in the space industry, its companies are also developing new constellations, such as the ADA Space and the ZeroG Lab companies, which are developing constellations capable of having minute-level Earth coverage (Nanosats, 2019). Ma et al. (2019), argued that the recent rapid development of China's commercial satellites might increase the cooperation among Belt and Road Countries (One Belt and One Road Initiative OBOR - a development strategy proposed by Chinese Government that focuses on connectivity and cooperation between Eurasian countries) through aerospace infrastructure, industrial alliance, service provision, among others. Xuan (2019) argued that in the next ten years the micro- and nanosatellite Chinese industry will reach 38.7 billion Chinese yuan (around 5.39 billion dollars), with the prediction of 1382 micro- and nanosatellites in orbit.

Nevertheless, Planet, from the USA, is the company that has been leading the development of CubeSats. The Company has launched more than 280 CubeSats since 2013 and nowadays operates more than 120 PlanetScopes (a constellation of $3 \mathrm{U}$ CubeSats), with nadir-viewing sensors, $3.7 \mathrm{~m}$ spatial resolution, 04 spectral bands: blue $(455-515 \mathrm{~nm})$, green $(500-590 \mathrm{~nm})$, red $(590-670 \mathrm{~nm})$, near-infrared $(780-860 \mathrm{~nm})$ and radiometric resolution of 14 bytes (Planet Team, 2017). The high number of satellites in orbit offers daily Earth coverage (Planet Team, 2017; McCabe et al., 2017b). Planet satellites cross the equator between 9:30 and 11:30 am (Planet Team, 2017) in orbit $475 \mathrm{~km}$ high and with a swath width of 24.6 resulting in tiles of 24.6 to $16.4 \mathrm{~km}$ (Planet Team, 2017). Table 1 shows the main commercial missions in orbit or planned.

Table 1. Commercial CubeSats Constellations.

\begin{tabular}{|c|c|c|c|c|c|}
\hline Organization & Launched / Planned & Form & First Launch & Country & Website \\
\hline Planet Labs & $355-150$ & $3 \mathrm{U}$ & 2013 & USA & https://www.planet.com/ \\
\hline Astro Digital & jun/25 & $6 \mathrm{U}$ & 2014 & USA & https://astrodigital.com/ \\
\hline Karten Space & $0-14$ & $6 \mathrm{U}$ & 2019 & Spanish & https://kartenspace.com/ \\
\hline Aistech Space & $25-150$ & - & 2018 & Spanish & https://aistechspace.com/ \\
\hline Reaktor Space & $\mathrm{jan} / 36$ & $2 \mathrm{U}$ & 2018 & Finland & $\overline{\mathrm{https}: / / \text { reaktorspace.com/ }}$ \\
\hline SatRevolution & $1-1024$ & $6 \mathrm{U}$ & 2019 & USA - Poland & https://satrevolution.com/ \\
\hline ADA Space & $1-192$ & - & 2018 & China & https://www.national-space.com/ \\
\hline ZeroG Lab & $2-132$ & $6 U$ & 2019 & China & https://url.gratis/iDjTW \\
\hline Hera Systems & $0-50$ & $12 \mathrm{U}$ & 2019 & USA & https://www.herasys.com/ \\
\hline Tekever & $0-12$ & $16 \mathrm{U}$ & 2020 & Portugal & https://www.tekever.com/ \\
\hline
\end{tabular}

Source: Nanosats (2019).

\section{SPECIALIZED NANOSATELLITES PROPOSALS}

This section presents studies showing the availability of new nanosatellites or CubeSats designed to meet specific applications, such as natural-disaster and water-resource monitoring. This section also reviews proposal missions published in academic journals. The new proposed nanosatellite missions are mainly focused on monitoring natural disasters and providing key information for efficient mitigation and restoration efforts, and for insurance companies, since those applications depend on continuous information at high spatial resolution. During natural disasters, fast, continuous and real-time observations are necessary. In this sense, nanosatellites and CubeSats constellations are very effective due to the high frequency of image acquisition (Santilli et al., 2018).

In this sense, Santilli et al. (2018) proposed a nanosatellite constellation for monitoring natural disasters in remote areas of Brazil, such as the Amazon region. The author simulated a nadir imaging nanosatellite constellation, $500 \mathrm{~km}$ high with a $3 \mathrm{~m}$ to $10 \mathrm{~m}$ spatial resolution 
and a revisit time of a few hours. The satellites would be in different orbits (different illumination conditions for each satellite) implying the need for a pre-processing phase to correct this effect. Furthermore, to increase the revisit time the satellites would carry flexible payloads, providing images off-nadir (Santilli et al., 2018), a condition that might increase glint effect (superficial water reflection of radiometric energy) decreasing the suitability of applications in aquatic environments (Overstreet and Legleiter, 2016). The high temporal resolution will be useful for increasing the number of cloud-free images in the Amazon region (Martins et al., 2018). However, the high number of images and the need for a pre-processing method to cope with the variable viewing and illumination geometry represent a main computational and processing challenge for the provision of real-time information, an essential condition for a fast response to natural disasters. In this sense, recent studies have been focused on new processing methodologies for improving computational performance (Zhang et al., 2018b; Shendryk et al., 2019).

Another constellation for monitoring natural disasters was proposed in Africa and Asia focusing on desertification, forest fires, inundation and locust infestation. The Cubesat has been designed with four 6U nanosatellites (Kameche et al., 2019). These satellites would carry an optical sensor with three spectral bands (green, red and near-infrared) with a revisit time of 72 hours.

To monitor water level and quality, African countries have proposed the SWEET (Sweet Water Earth Education Technologies). The mission goal is to provide information on cyanobacterial blooms in order to guarantee drinking water for human consumption (Antonini et al., 2017). The constellation was designed with four nanosatellites (2U) carrying hyperspectral sensors with spectral resolution ranging between 10 to $30 \mathrm{~nm}$ in the 500 to 900 $\mathrm{nm}$ range. The spatial resolution is proposed to be $250 \mathrm{~m}$, enough for capturing 62 African lakes with a 10x10 pixel size (lakes with at least $1370 \times 1370 \mathrm{~m}$ ) with a revisit time of 2.5 days (Antonini et al., 2017). Once successful in Africa, the SWEET constellation would be then expanded globally (Antonini et al., 2017).

\section{EXPERIMENTAL NANOSATELLITE ANALYSIS}

This section describes the first image analysis from experimental nanosatellites launched from universities and private companies. These studies are important since they test new payloads and technological innovations that might be implemented in future nanosatellite constellations. Chinese universities have been investing in nanosatellites for supplying the growing space demand in science and industry. Wu et al. (2017) described the first Chinesedesigned and implemented CubeSat, a 3U called STU-2A developed to monitor the impact of climate change on glacier dynamics and reduction. The satellite sensor has visible bands with $94 \mathrm{~m}$ spatial resolution and an inclination of $97.3^{\circ}$. The sensor was calibrated and validated with MODIS data. Since the STU-2A was specifically designed for polar regions, the camera performed better than MODIS, which in high latitudes is subject to low solar angle and oversaturation.

Another Chinese nanosatellite, a 6U called Luojia 1-01, was developed to capture nighttime light imagery. The Luojia 1-01 has a spatial resolution of $100 \mathrm{~m}$ and its sensor is composed of $2048 \times 2048$ detectors to capture the weak nighttime light (Zhang et al., 2018a). This kind of information is useful to track anthropogenic activity and its economic impacts (Huang et al., 2016; Pandey et al., 2013). Luojia 1-01 information has been applied to investigate artificial light pollution (Jiang et al., 2018), urban extend (Li et al., 2018), providing parameters for socio-economic modeling (Zhang et al., 2019), estimation of urban-housing prices (Li et al., 2019a), weak nighttime illumination from small communities and cities (Li et $a l ., 2019 \mathrm{~b}$ ), among others. The Luojia 1-01 is a prototype for a future nanosatellite constellation.

Rev. Ambient. Água vol. 15 n. 3, e2513 - Taubaté 2020 
In Germany, Barschke et al. (2017) described a nanosatellite called TUBIN (Technische Universität Berlin Infrared Nanosatellite), which was developed based on the nanosatellite TUBiX20 platform. The satellite was designed to validate an infrared microbolometer for wildfire remote sensing. The TUBIN payload is composed of a thermal infrared microbolometer array (TIR) and a visible camera.

As described, nanosatellite lower-cost production is allowing developing countries to invest in space missions. Mhangara et al. (2020) studied the image quality of the nSight-1 nanosatellite developed by a South African company and launched as part of the European Commission-funded international QB50 constellation. One of the three payloads is a Gecko imager with a swath width of $64 \mathrm{~km}, 30 \mathrm{~m}$ spatial resolution, and visible bands. The nSight-1 satellite captures images only in pre-programmed target areas, thus improving the revisit time in those areas (Mhangara et al., 2020). These imagery analyses of nanosatellite prototypes are important to identify areas for improvement and are a requirement before launching definitive nanosatellite constellations.

\section{NANOSATELLITE APPLICATIONS FOR EARTH REMOTE SENSING}

Most of the literature on nanosatellite remote sensing refers to the application of PlanetScope and Doves images, from Planet Labs, which is the first and unique operational and private nanosatellite constellation providing data regularly. Through exhaustive investigation, we identified 63 articles published in international remote-sensing journals from 2016 to March 2020 using PlanetScope or Doves constellation. Most of the papers are related to vegetation, followed by natural disasters (oil split, landslides, earthquakes, volcano monitoring, extreme weather and fire), oceanography and inland waters. Despite the smaller number of articles in Africa, from Figure 1 it is possible to observe the great spatial distribution of PlanetScope and Doves studies in the world and the rapid increase in the number of articles from 2016 to 2020 (bar graph below the image). Articles regarding different subjects, such as topography estimation, land cover, geology and carbon mapping were classified as "others". From the review, some articles were selected to discuss and understand the implementation of nanosatellite technology to real world remote-sensing products.

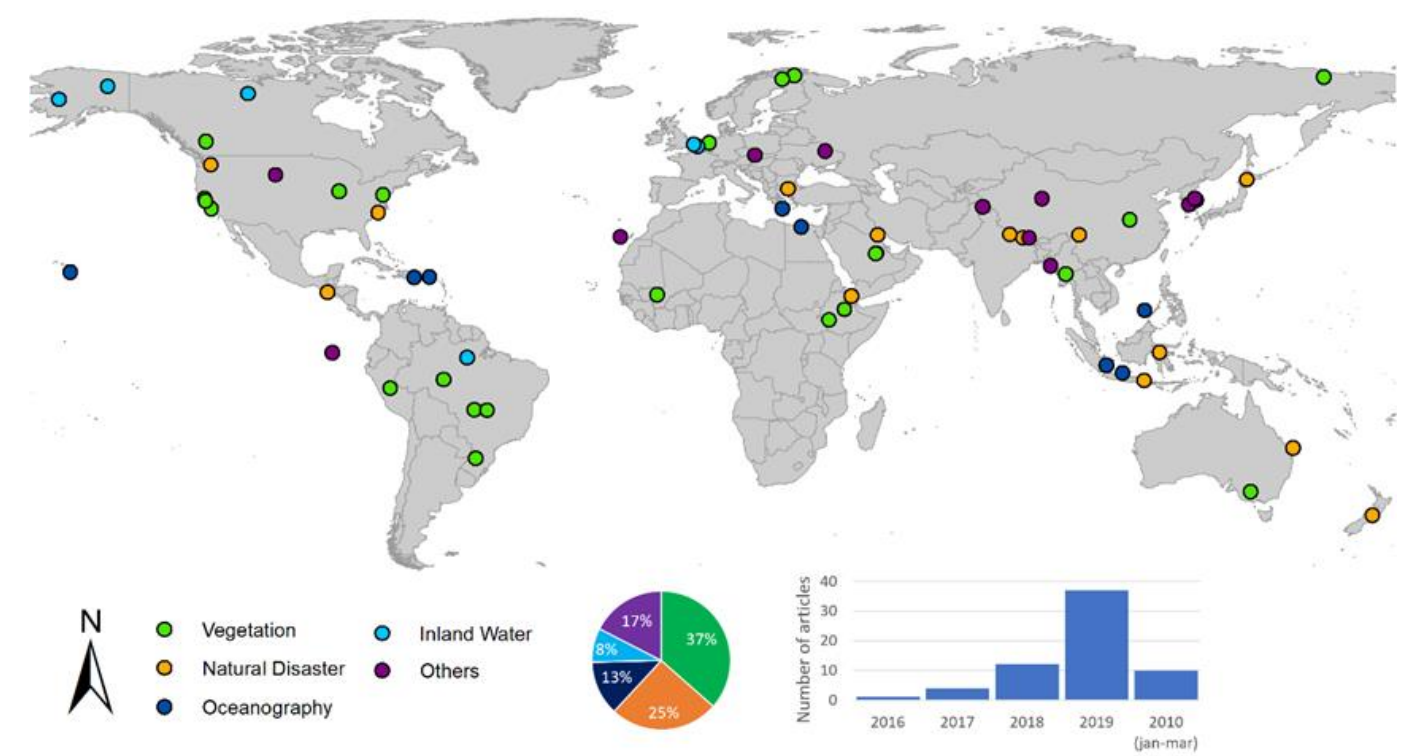

Figure 1. Study locations of articles that used PlanetScope or Doves constellations. The below pie graph chart shows the percentage of studies in each category and the bar graph shows the number of published articles in each year. 
The application of CubeSats is promising in vegetation, especially for precision agriculture and environmental monitoring. These high-detail and frequent images might be used to identify spatial variability between and within fields to support water and nutrient management at the farm scale (Aragon et al., 2018). In this sense, different methodologies have been proposed to retrieve CubeSat information for crop monitoring. Even though vegetation targets have higher reflectance in various bands in relation to water bodies, the retrieval of accurate information requires high-quality sensors to provide accurate results.

Houborg and McCabe (2016), for instance, developed a fusion methodology for computing NDVI (Normalized Difference Vegetation Index) using Doves RGB and Landsat 8 images. This methodology was proposed to overcome the lack of Dove's near-infrared band, by applying a cubic regression relating Landsat 8 NDVI Doves red and green radiance measurements. The method consisted of resampling all the images to $30 \mathrm{~m}$ resolution, and computing the Green-Red Vegetation Index (GRVI), which was then used with the higher radiometric resolution image in a regression model to compute the NDVI. Finally, the NDVI was resampled to $3.5 \mathrm{~m}$ with both high-spatial and radiometric resolution, ideal to track agricultural biomass. NDVI Doves and the NDVI Landsat validation resulted in $\mathrm{r}^{2}=0.99$ and $\mathrm{MAD}=9 \%$. The main limitation of the proposed method comes from the fact that Landsat and Dove images limits the high temporal resolution provided by CubeSat constellations. The same method was also applied to compute the Leaf Area Index (LAI), which was then used as an input to the Priestley Taylor Jet Propulsion Laboratory (PT JPL) evaporation model (McCabe et al. 2017b; Aragon et al. 2018). Aragon et al. (2018) results (Figure 2) indicated that PlanetScope ET explained $86 \%$ of the observed field variability and RMSE $=32.9 \%$ of the irrigated maize, with a trend of underestimating surface moisture conditions. They were also able to estimate water consumption, which is valuable information for water management. The method also permitted the computation of irrigation efficiency at the pivot level.

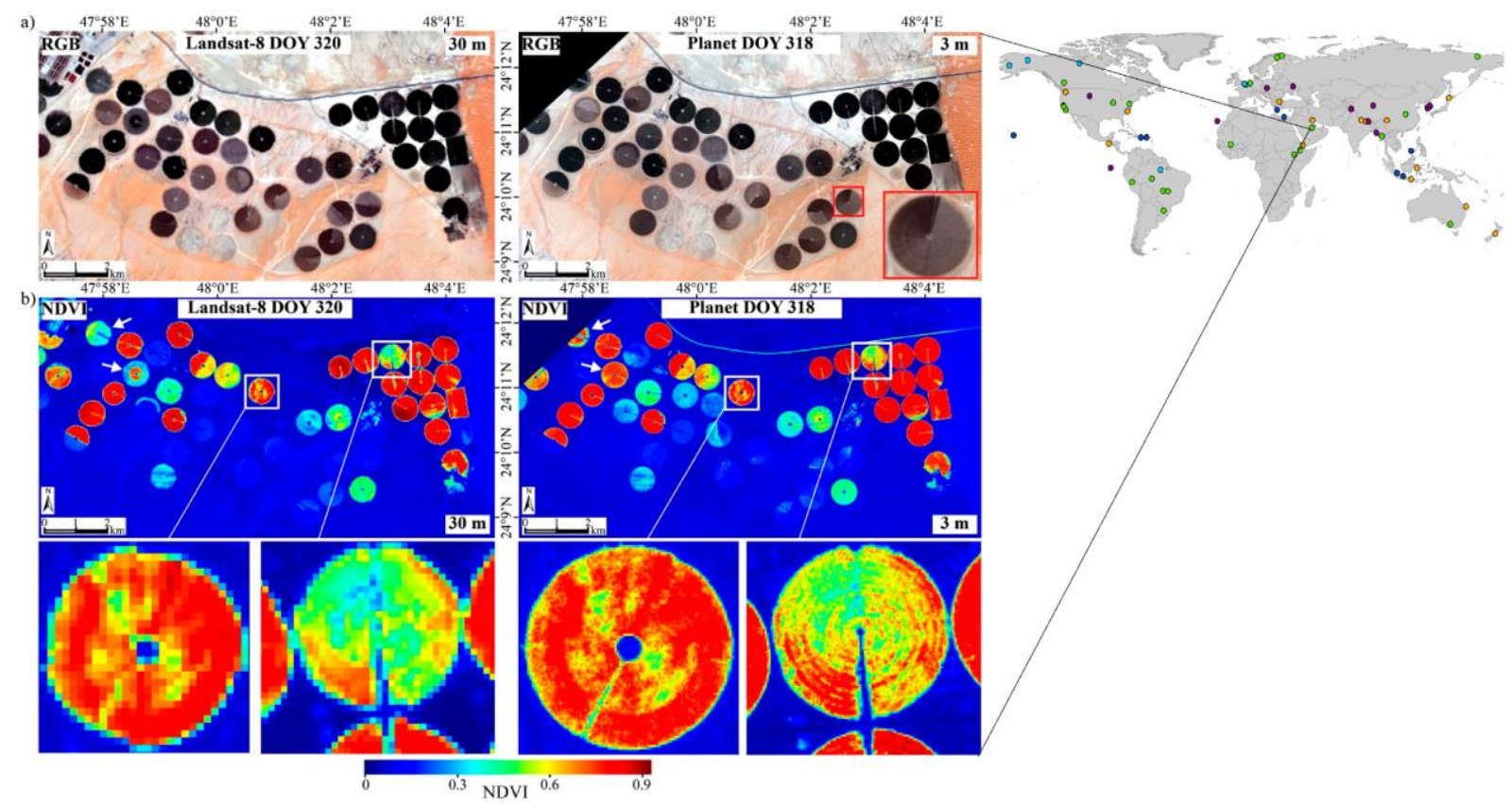

Figure 2. (a) True-color RGB imagery from Landsat- 8 and Planet acquisitions two days apart. (b) Intercomparison of Landsat-8 NDVI and Planet NDVI computed from RGB imagery using Cubist regressions generated on the basis of Landsat- 8 training data. The two white arrows highlight fields that have undergone significant change in cover conditions between the two acquisitions.

Source: Modified Houborg and McCabe (2016).

The combination of high-spatial PlanetScope resolution data with small aerial systems also

Rev. Ambient. Água vol. 15 n. 3, e2513 - Taubaté 2020 
has been tested. Liu et al. (2019), for example, have improved even further the already high resolution of the Planet images fusing PlanetScope with monthly Small Unmanned Aerial System (sUAS) images to produce daily forage production estimates, with $30 \mathrm{~cm}$ spatial resolution, from 2017 to 2018. To do so, the authors firstly interpolated cloud-free NDVI PlanetScope images, to have daily information. The results showed a good correlation $\left(\mathrm{R}^{2}=0.8\right.$ and RMSE of $542 \mathrm{~kg} / \mathrm{ha}$ ) between the field measurements and forage production.

Shi et al. (2019) have also used vegetation indices to estimate vegetation variables. The authors used PlanetScope images to assess infected crops with great details using two dates, 21 August and 30 October 2017 (Shi et al., 2019). The authors developed a normalized two-stage vegetation index (VIs) to characterize temporal developments of the NDVI, SAVI (Soiladjusted vegetation index), RDVI (re-normalized difference vegetation), TVI (Triangular vegetation index), MSR (Modified Simple Ratio) and SIPI (Structural Independent Pigment Index) for PlanetScope images. The authors used a VI two-stage as a parameter in the partial least-square discriminant analysis (PLS-DA). The PLS is a multivariable statistical method based on the principal components and was used to find a correlation between vegetation indices variation and disease species. The results showed that the single-stage VI was able to discriminate between healthy and unhealthy samples, while the two-stage VI was able to discriminate between different infestations (rice dwarf, rice blast and glume blight diseases). Rice disease overall classification accuracy was $75.62 \%$ with a Kappa value of 0.47 . Therefore, PlanetScope images were successfully applied for high-spatial resolution monitoring of rice disease (Shi et al., 2019).

Using a combination of vegetation indices and classifications methods, such as SVM (Support Vector Machine), CUB (Cubist) and SGB (Stochastic Gradient Boosting) in PlanetScope images in a region of Rio Grande do Sul state - Brazil, Breunig et al. (2020) were able to estimate cash-crop yield based on above-ground biomass. The overall accuracies ranged from $61.20 \%$ and $68.25 \%$ and the NDVI and EVI vegetation indices were the most important predictors of cash-crop yield with correlation coefficient ranging from +0.7 for forage turnip and +0.78 for rye.

As informed, the high temporal resolution promoted by constellations of nanosatellites are very effective for monitoring natural disasters (Santilli et al., 2018). Furthermore, the high spatial resolution from Planet satellites might also be applied to monitor events in high detail, improving field mitigation actions. However, the processing time necessary to compute these vast amounts of data must be reduced to generate information quickly in an emergency situation. Park et al. (2019), for example, applied an artificial neural network (ANN) for the detection of oil slick areas in Kuwait in August 2017, using a methodology to reduce the processing time. Sunlight wave effects were removed using a median filter previous to the ANN classification, which provided an overall accuracy of $82.01 \%$ with a Kappa coefficient of 72.42. The daily revisit of PlanetScope proved useful in ocean oil-spill emergencies. Aldeghi et al. (2019), by the other hand, used the Doves constellation to track volcanic activity in the Fuego Volcano (Guatemala), one of the most active in the world. The combination of high spatialtemporal resolution allowed the authors to map ash clouds, lava flows and pyroclastic density currents before, during and after an eruption.

The monitoring of inland water using remote sensing information is difficult. Inland waters are composed of different optical active components that vary in space (different regions) and time (seasons). Furthermore, water-leaving radiance is usually low (Jorge et al., 2017), which impacts the STN, especially in longer wavelengths. These conditions require sensors with high radiometric quality, a challenge for the cheaper sensors on board the CubeSat.

PlanetScope images are useful to track inundation areas, since this information does not depend on high radiometric quality. In this sense, Cooley et al. (2017) identified monitoring inundation patterns in lakes along the Yukon River, North Alaska, using PlanetScope 
information. The images were acquired from June to August 2016 at 3A level - no atmospheric correction. The authors used the Normalized Difference Water Index (NDWI), which is a rate between green- and near-infrared bands, for classifying inundation zones. To assess the accuracy of the inundated area, the authors mapped the lake area using WorldView-2 \& 3 images which were then related to the PlanetScope area. The relationship between lake area provided by WorldView and Planetscope images was high $\left(\mathrm{r}^{2}>0.99\right)$, but the normalized root mean square (NRMSE) varied between $10.9 \%$ and $12.6 \%$ due to time difference between two consecutive image acquisitions. River-lake connectivity was measured by analyzing the relationship between the main river width (a proxy of discharge) and time changes in the lake area. As informed, this study did not depend on PlanetScope radiometric quality, since only spatial properties were measured, such as the lakes area and river width. The same authors argued that in low-relief environments the temporal variation of a lake's extent is a good indicator of river-lake connectivity (the authors selected only lakes with area higher than 10.000 $\mathrm{m}^{2}$ to measure the connectivity). However, the variability of the lake's area depends highly on its extension and surrounding topography (a large lake requires a higher input of water to change its superficial area). This potential connectivity bias was not measured. In Figure 3, it is possible to observe that larger lakes were classified as stable (small variation of water surface area).
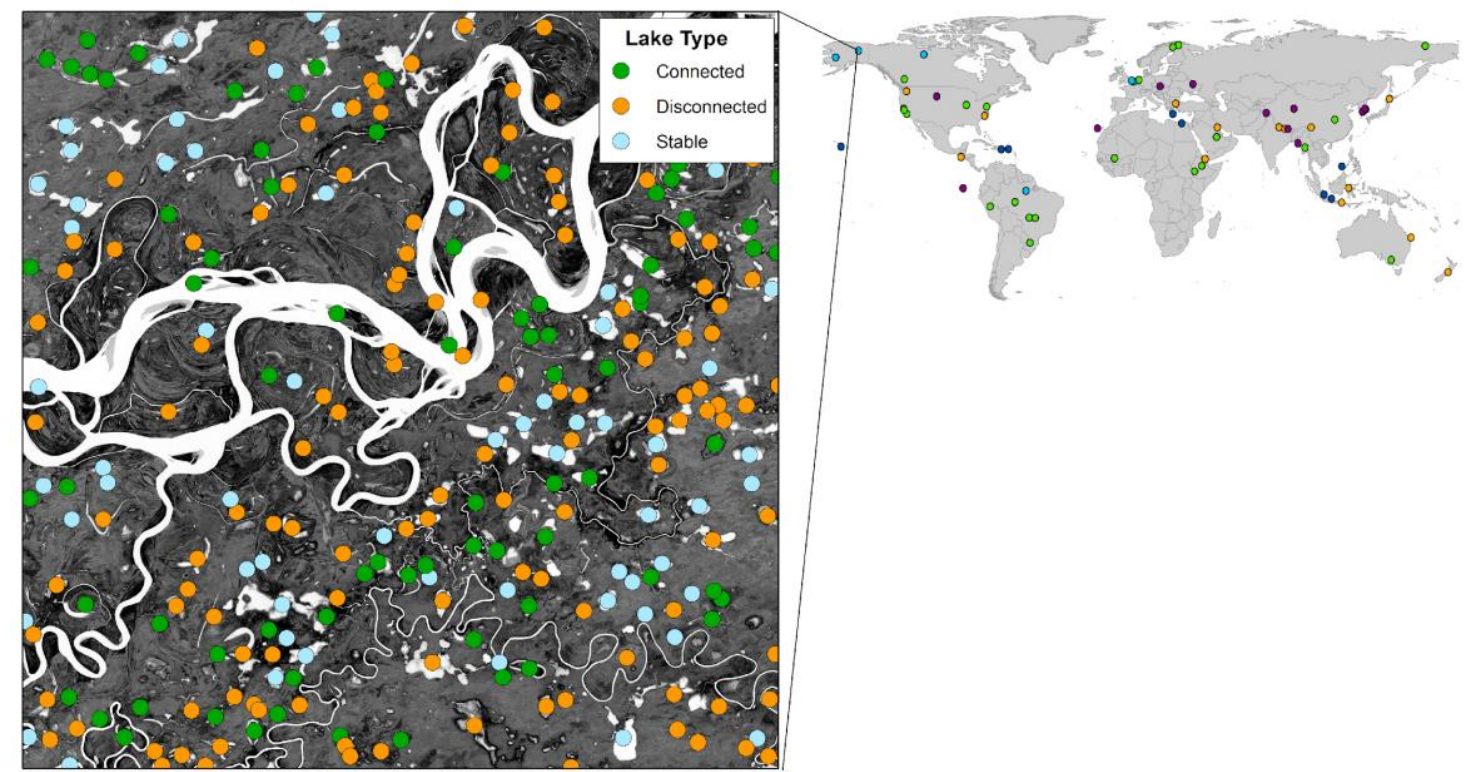

Figure 3. Temporal correlation between Planet time-series and Yukon River discharge.

Source: Modified by Cooley et al. (2017).

Using a similar spatial-analysis methodology, PlanetScope (without atmospheric correction images) was used to monitor approximately 85,000 lakes in the Arctic Boreal region, from 1 May to 1 October 2017 (Cooley et al., 2019). Due to geolocation uncertainty (> $10 \mathrm{~m}$ ), the authors analyzed the lake area variation within a $60 \mathrm{~m}$ buffer around the lake mask. The authors tracked seasonal changes in the water-surface area for each lake. Since the data included uncertainties caused by clouds, ice cover, poor classification and low signal-to-noise ratio (SNR), the authors categorized the lakes as "valid" or "invalid", according to a manually validated training data set. Based on the valid data, the authors analyzed minimum and maximum differences of each lake. This information was then used to classify the valid lakes according to their rate of change $\left(\mathrm{Km}^{2} / \mathrm{Km}^{2}\right)$ along with the time series. In both papers (Cooley et al., 2017; 2019), PlanetScope images were crucial to analyze fast hydrologic variations in small lakes, thanks to its high temporal and spatial resolution. It is important to highlight, 
however, that geolocation uncertainty and radiometric and environmental sources of error reduced the sample size to a subset of valid lakes.

Another interesting application of PlanetScope images (Kääb et al., 2019) was the use of time lapses in image acquisition for estimating river water velocity in cold regions. The authors tracked ice movement using consecutive images by tracking the ice movement through consecutive PlanetScope images. The time-lapse of the 90s between images made it possible, according to the authors, to estimate the water speed of the Amur River (Siberia) and the Yukon River (Alaska), with an accuracy of $\pm 0.01 \mathrm{~m} / \mathrm{s}$. The main limitations of PlanetScope in that application are the lack of cross-track overlaps for the entire Earth, cloud cover, the need for freeze-up conditions and sun glint (when the sun angle is too low to acquire suitable images).

Despite PlanetScope's radiometric limitations, their images have been applied for retrieving water-quality parameters. PlanetScope has been applied to map turbidity in the San Francisco Bay Area (Vanhellemont et al., 2019). The authors adapted a Dark Spectrum Fitting (DSF) aerosol correction to the images and neural network to red band for identifying turbidity classes spanning from clear to moderate. According to the authors, turbidity estimates were comparable to those of Sentinel-2 /MSI estimates, which supports PlanetScope's application for monitoring moderate turbidity $<80 \mathrm{NFU}$ (Formazin Nephelometric Units). Maciel et al. (2020) reported a higher correlation between PlanetScope red Remote Sensing Reflectance (red Rrs) and TSS (Total Suspended Solid), TSI (Total Suspended Inorganic Solid) and Secchi Depth with $\mathrm{R}^{2}>0.74$ and MAPE $<38 \%$ in very turbid lakes of the lower Amazon floodplain.

The use of CubeSats to monitor oceanography faces the same low STN as inland-water monitoring. However, due to the high-water transparency, most studies are focused on methodologies for mapping the depth and underwater characteristics of the seabed in relatively shallow waters. Poursanidis et al. (2019) used PlanetScope images to estimate coastal bathymetry in a region of the island of Crete (Greece), using images on level 3B - orthorectified and atmospherically corrected. The authors used an empirical method based on the relationship between field bathymetry data (9954 points) and radiometric information from the blue, red and green PlanetScope bands to calibrate and validate an empirical model. According to the authors, estimates of Root Mean Square Error (RMSE) of $0.32 \mathrm{~m}$ were observed for depths between 0 and $10 \mathrm{~m}$, while in depths between 10 and $25 \mathrm{~m}$, the RMSE was $1.58 \mathrm{~m}$. These errors fit the requirements established by the International Hydrographic Organization at the Category Zone of Confidence, allowing the inclusion of those bathymetric charts in navigation maps. However, the authors used a single image to calibrate the empirical model, restricting the study area to a small portion of coastal Crete. Due to differences in PlanetScope sensors, the calibration of a model in a larger area (comprising more than one image) would increase result uncertainties.

To monitor the underwater seabed, some studies have applied classification algorithms. Wicaksono and Lazuardi (2018), for example, assessed benthic and seagrass species in optically shallow water using PlanetScope images. The authors pre-processed the images using atmospheric correction, Minimum Noise Fraction and Linear Spectral Unmixing and mapped just areas with depth higher than $11.6 \mathrm{~m}$. The fraction images were then classified using different types of classification algorithms for benthic habitat (Kappa of 0.33) and for seagrass species areas (Kappa 0.53). The authors argued that the low PlanetScope STN ratio, especially in the ocean, and the similarities among the classes outperformed the classification. However, although the recognized challenge of obtaining information from underwater, the sample collection to validate and calibrate the algorithms was not well-distributed along the study area (calibration and validation sample points were too close to some specific spots of the study area). In this sense, the methodology might artificially decrease the spatial variability and thus super estimate the statistical accuracy coefficients.

A similar study was carried out at An Chan Coastal Waters (Vietnam) where PlanetScope (level 1B) was applied for seagrass mapping (Hang et al., 2019). The authors first correct all 
bands for bottom effects using the Bottom Reflectance Index algorithm (BRI), and then the corrected images were classified using the Maximum Likelihood. The results showed an overall and Kappa coefficient of $92.52 \%$ and 0.8957 , respectively. For estimating seagrass biomass, both linear and multiple regression models were tested using 56 biomass samples and BRI measured in concurrently acquired PlanetScope bands. The BRI Red band performed better, with $\mathrm{R}^{2}=0.9707$ and $\mathrm{RMSE}= \pm 109.21 \mathrm{~g} / \mathrm{m}^{2}$.

In the same way, Asner et al. (2017) used classification methodologies to assess coral reefs in the South China Sea (China, Vietnam, Malaysia, and the Philippines) using Doves images (RGB bands) from the Planet Company. The authors used different types of classification algorithms, with the best result provided by an unsupervised algorithm (ISODATA) with 92\% overall accuracy using three classes: observable deep reef (>10 m depth), shallow reef and sand. Although Doves images have not allowed distinguishing between seagrass and shallow reefs, the images permitted the observation that occupied atolls had smaller reef proportions than those unoccupied. The use of Doves image in this study was crucial to monitor the reefs, as Landsat images were all cloudy during the period. Furthermore, the Doves high-spatial resolution images $(3.7 \mathrm{~m}$ ) allowed the assessment of details in coral reefs, which would be impossible to monitor using traditional satellites (Asner et al., 2017). Figure 4 shows the products generated by PlanetScope images.

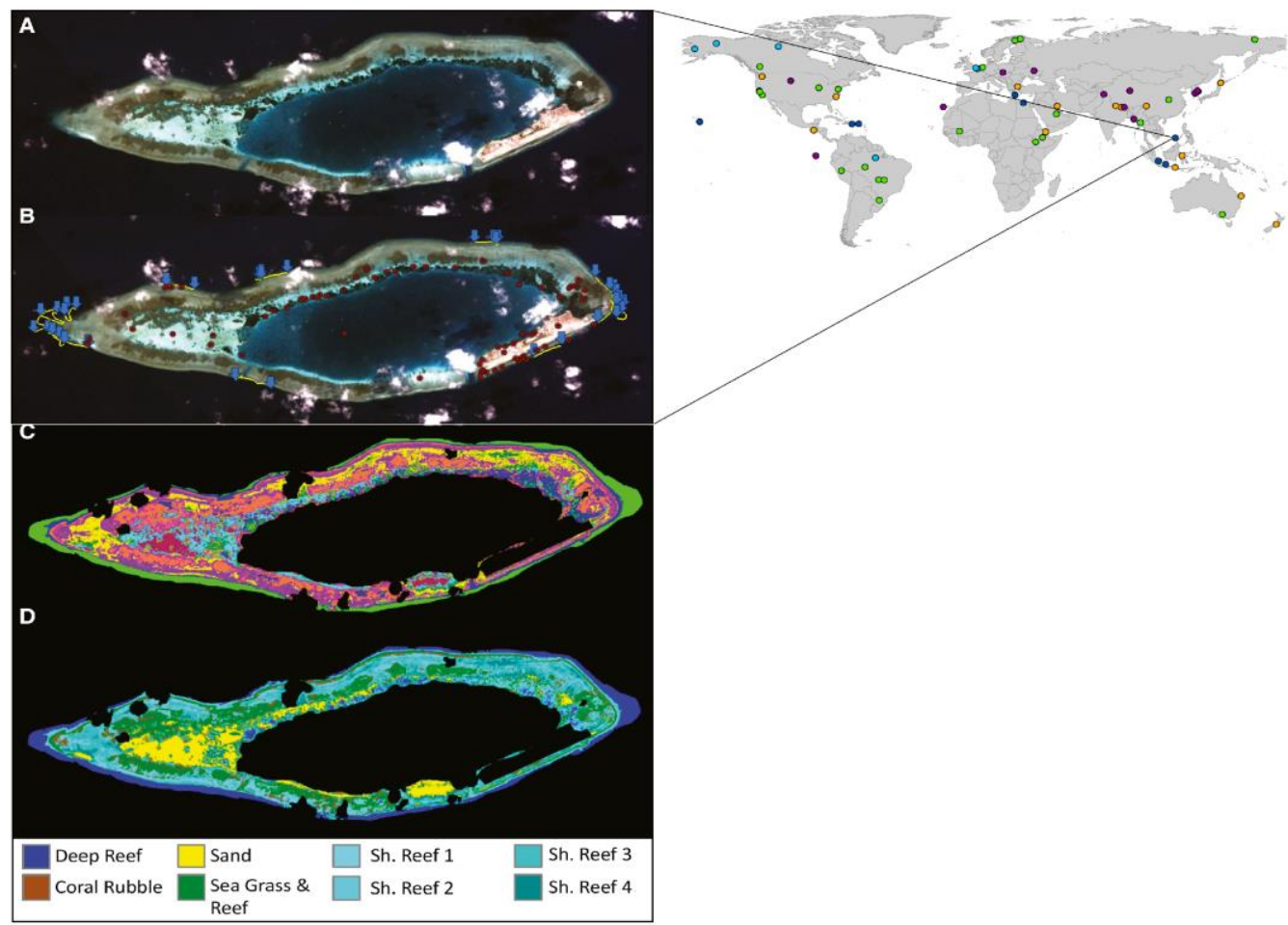

Figure 4. (A) Planet Dove natural color composition image in Pulau Layang Layang. (B) Location of in-water survey transects (yellow lines and blue arrows) and observation points (red) used for classification assessment. (C) Fourteen class results from ISODATA analysis. (D) Recombination. Source: Modified by Asner et al. (2017).

Although most of the CubeSats applications are focused on vegetation, followed by natural disasters, oceanography and water resources, there is a range of other possible applications. Ghuffar (2018), for example, constructed a Digital Elevation Model (DEM) using two PlanetScope images of the Khurdopin glacier (Pakistan) using multi-view stereo matching algorithms with two sequential minute difference PlanetScope images. The results showed an Absolute Deviation (NMAD) of $4.1 \mathrm{~m}$ between Planet DEM and Lidar reference. According to 
the authors, the method is useful for monitoring disasters such as avalanches and landslides thanks to the daily PlanetScope coverage.

\section{LIMITATIONS}

The nanosatellites' low-cost advantage comes with some limitations. The sensors onboard nanosatellites and Cubesats have some important constraints, caused by their low satellite component price and short development time. PlanetScope sensors have a low radiometric resolution (low sensibility to earth reflective energy), challenging applications that demand high signal sensitivity, such as ocean color and water-quality monitoring. The low signal to noise ratio (SNR) and the high signal instability related to sensor intercalibration within the satellite constellation also represent serious constraints for applications, which demand accurate radiometry along with time-series. CubeSat constellations also impose different times of satellite overpass with the implication in viewing geometry taxing the quality of the radiometric calibration from sensor to sensor. The narrow spectral range $(455-860 \mathrm{~nm})$ and low spectral resolution also limit its uses in other analyses, such as distinguishing between cloud, snow, ice, and water. The PlanetSCope sensor also has overlapping and broader spectral bands, which limits its application (Houborg and McCabe, 2018). Moreover, the lack of the infra-red band in the DOVE constellation also limits sun-glint removal, reducing its potential for water-related applications (Asner et al., 2017). The PlanetSCope sensor, despite the presence of a nearinfrared band, can't be applied for sun-glint correction in clear waters, due to the low nearinfrared band STN (Wicaksono and Lazuardi, 2018). Another limitation (Cooley et al., 2017) of PlanetScope images are related to the geolocation uncertainty and the lack of an algorithm for cloud and cloud shadow detection.

The low SNR, combined with its restricted spectral resolution, limits PlanetScope images to the analyses of water resources that require narrow spectral bands, especially for water quality parameters (sediment, pollution, chlorophyll a and b). Despite these limitations, Maciel et al. (2020) and Vanhellemont et al. (2019) found a satisfactory correlation between the red band and medium to high turbidity water. Maciel et al. (2020) argued that in clear waters, the PlanetScope images were badly influenced by the low SNR, glint and adjacency effects. Furthermore, fusion methodologies used in vegetation papers to correct PlanetScope radiometric resolution, as made by Houborg and McCabe (2016) and Wicaksono and Lazuardi (2018), might possibly be applied to study water optical active components, such as chlorophyll-a, phycocyanin or colored dissolved organic matter (CDOM).

So far, vegetation studies using CubeSats images, namely PlanetScope and Doves from the Planet company, have used fusion techniques to improve their radiometric and even spatial resolution (with other satellite or Unmanned Aerial System images). These methodologies might be transferred for use in other challenging areas, such as water resources, as mentioned previously. However, Shi et al. (2019) successfully used PlanetScope images, from two dates, to identify crop diseases, a complex detection approach.

\section{FINAL CONSIDERATIONS}

The daily high spatial Earth coverage, promoted by PlanetScope constellation, illustrates how the space industry is evolving. The amount of spatial data is increasing at a rapid pace, as observed and illustrated by the future planned commercial constellations, and will require new ways of computing, processing and storing data. This data will increase monitoring on a global scale, which might help study complex natural processes and protect fragile environments.

So far, all the CubeSat remote-sensing scientific applications used Planet company constellations (Doves and PlanetScope). This shows that the private sector is leading the development of nanosatellites for Earth observation. That was possibly due to the CubeSat's 
shorter development and production cycle. However, the PlanetScope and Doves image costs restrict their use, especially in long historic-analysis research. In this sense, and due to better sensor quality, open-source data provided by national agencies' satellites will continue to be popular among users. A decade ago, Sandau (2010) argued that CubeSats and nanosatellites were still viewed as complementary to large satellites rather than competitive standalone missions. However, as the CubeSat technology advances, the trend is to use their images to replace bigger ones. One example is the Brazilian government's attempt to use Planet images to track Amazon deforestation, a service already done by the National Institute for Space Research (INPE), that uses the China-Brazil Earth Resources Satellite (CBERS-4) and AWiFS, an Indian remote-sensing satellite.

Despite the expansion of remote sensing areas monitored by CubeSats, there are still sensor quality challenges to overcome before the scientific community can prescind traditional large satellites. For example, in the PlanetScope constellation, the main limiting factors are related to its variability of sensors calibration, low radiometric quality and sunglint effect. By mitigating these constraints, PlanetScope and other planned constellations, with their high-spatial and temporal resolution, might expand remote-sensing applications.

The CubeSat and Nanosatellites' lower cost is allowing interested sectors to propose huge commercial constellations and specialized satellites to correspond to specific demands. Private companies are planning constellations that might reach minute-level revisit time. Adding to the remote-sensing field, communication CubeSats are filling up space, like the Project Kuiper, which aims to launch 3,236 internet-connectivity CubeSats. All of these proposed releases raise a space satellite crowd issue, as potential collisions between satellites increase, which would generate enormous amounts of space debris and hit other satellites, in a cascade effect.

CubeSats and Nanosatellites opened an era of space democratization that is leading to fast development in their design, microsystem and electronic components, at the same time that launch failures are reduced. This rapid progress, associated with the already spatial and temporal advantages, permitted these satellites to become more popular over the years. The large satellite-era is being replaced by an era of smaller and nimbler satellites.

\section{ACKNOWLEDGEMENTS}

The authors would like to acknowledge financial support from the Conselho Nacional de Desenvolvimento Científico e Tecnológico (CNPq), Coordenação de Aperfeiçoamento de Pessoal de Nível Superior - Brasil (CAPES) and FAPESP 2018/12083-1.

\section{REFERENCES}

AISTECH SPACE. Aistech: Access to Intelligent Space Technologies. 2019. Available at: https://aistechspace.com/. Access: March 2020.

ALDEGHI, A.; CARN, S.; ESCOBAR-WOLF, R.; GROPPELLI, G. Volcano Monitoring from Space Using High-Cadence Planet Cubesat Images Applied to Fuego Volcano, Guatemala. Remote Sensing, v. 11, n. 18, 2019. https://doi.org/10.3390/rs11182151

ANTONINI, K.; LANGER, M.; FARID, A.; WALTER, U. SWEET CUBESAT - Water Detection and Water Quality Monitoring for the 21st Century. Acta Astronautica, v. 140, 2017. https://doi.org/10.1016/j.actaastro.2017.07.046

ARAGON, B.; HOUBORG, R.; TU, K.; FISHER, J. B.; MCCABLE, M. CubeSats Enable High Spatiotemporal Retrievals of Crop-Water Use for Precision Agriculture. Remote Sensing, v. 10, n. 12, 2018. https://doi.org/10.3390/rs10121867 
ASNER, G. P.; MARTIN, R. E.; MASCARO, J. Coral reef atoll assessment in the South China Sea using Planet Dove satellites. Remote Sensing in Ecology and Conservation, v. 3, n. 2, p. 57-65, 2017. https://doi.org/10.1002/rse2.42

ASTRO DIGITAL. Space-Based Solutions Solving Real World Challenges. 2018. Available at: https://astrodigital.com/. Access: Sep. 2019.

BARSCHKE, M. F.; BARTHOLOMÄUS, J.; GORDON, K.; LEHMENN, M.; BRIE, K. The TUBIN nanosatellite mission for wildfire detection in thermal infrared. CEAS Space, v. 9, p. 183-194, 2017. https://doi.org/10.1007/s12567-016-0140-6

BREUNIG, F. M.; GALVÃO, L. S.; DALOGNOL, R.; DAUVE, C. E.; PARRAGA, A.; SANTI, A. L.; FLORA, D. P.; CHEN, S. Delineation of management zones in agricultural fields using cover-crop biomass estimates from PlanetScope data. International Journal of Applied Earth Observation and Geoinformation, v. 85, 2020. https://doi.org/10.1016/j.jag.2019.102004

CAMPS, A. Nanosatellites and Applications to Commercial and Scientific Missions. Ionospheric and Atmospheric Threats for GNSS and Satellite Telecommunications, 2019. http://dx.doi.org/10.5772/intechopen.90039

COOLEY, S. W.; SMITH, L. C.; STEPAN, L.; MASCARO, J. Tracking Dynamic Northern Surface Water Changes with High-Frequency Planet CubeSat Imagery. Remote Sensing, v. 9, n. 1306, p. 1-21, 2017. https://doi.org/10.3390/rs9121306

COOLEY, S. W.; SMITH, L. C.; STEPAN, L.; MASCARO, J. Arctic-Boreal lake dynamics revealed using CubeSat imagery. Geophysical Research Letters, v. 46, p. 2111-2120, 2019. https://doi.org/10.1029/2018GL081584

COPERNICUS MASTERS. FSSCat-Towards Federated EO Systems. Available at: https://www.copernicusmasters.com/winner/ffscat-towards-federated-eo-systems/ Access: March 2020.

CRUSAN, J.; GALICA, C. Nasa's CubeSat launch initiative: Enabling broad access to space. In: INTERNATIONAL ASTRONAUTICAL CONGRESS, IAC, 2016, Guadalajara, Mexico., Proceedings[...] Mexico, 2016.

DAVOLI, F.; KOUROGIORGAS, C.; MARCHESE, M.; PANAGOPOULOS, A.; PATRONE, F. Small satellites and CubeSats: Survey of Structures, Architectures, and Protocols. International Journal of Satellite Communications and Networking, p. 1-17, 2018. https://doi.org/10.1002/sat.1277

DEUTSCH, C. A.; TEWKSBURY, J. J.; TIGCHELAAR, M.; BATTISTI, D. S.; MERRILL, S. C.; HUEY, R. B.; NAYLOR, R. L. Increase in crop losses to insect pests in a warming $\begin{array}{lllllll}\text { climate. Science, } & \text { v. 361, n. 6405, p. 916-919, } 2018 .\end{array}$ http://dx.doi.org/10.1126/science.aat3466

ESA. eoPortal Directory. Available at: https://earth.esa.int/web/eoportal/satellitemissions/a/aalto-1. Access: March 2020.

FLANNIGAN, M. D.; STOCKS, B. J.; WOTTON, B. M. Climate change and forest fires. Science of the total environment, v. 262, n. 3, p. 221-229, 2000. https://doi.org/10.1016/S0048-9697(00)00524-6

FLANNIGAN, M. D.; BRIAN D. A.; KIM A. L.; BRIAN J. S.; MIKE W. B. Forest fires and climate change in the 21 st century. Mitigation and adaptation strategies for global change, v. 11, n. 4, p. 847-859, 2006. https://doi.org/10.1007/s11027-005-9020-7 
GHUFFAR, S. DEM Generation from Multi Satellite PlanetScope Imagery. Remote Sensing, v. 10, n. 9, 2018. https://doi.org/10.3390/rs10091462

GILLETT, N. P.; WEAVER, A. J.; ZWIERS, F. W.; FLANNIGAN, M. D. Detecting the effect of climate change on Canadian forest fires. Geophysical Research Letters, v. 31, n. 18, 2004. https://doi.org/10.1029/2004GL020876

HANG, N. T. T.; HOA, N. T.; SON, T. P. H.; NGOC, L. N. Vegetation Biomass of Sargassum Meadows in An Chan Coastal Waters, Phu Yen Province, Vietnam Derived from PlanetScope Image. Journal of Environmental Science and Engineering, v. 8, p. 8192, 2019. https://dx.doi.org/10.17265/2162-5263/2019.03.001

HOUBORG, R.; MCCABE, M. F. High-Resolution NDVI from Planet's Constellation of Earth Observing Nano-Satellites: A New Data Source for Precision Agriculture. Remote Sensing, v. 8, n. 768, p. 1-19, 2016. https://doi.org/10.3390/rs8090768

HOUBORG, R.; MCCABE, M. F. A Cubesat enabled Spatio-Temporal Enhancement Method (CESTEM) utilizing Planet, Landsat and MODIS data. Remote Sensing of Environment, v. 209, p. 211-226, 2018. https://doi.org/10.1016/j.rse.2018.02.067

HUANG, X.; SCHNEIDER, A.; FRIEDL, M. A. Mapping sub-pixel urban expansion in China using MODIS and DMSP/OLS nighttime lights. Remote Sensing of Environment, v.175, p. 92-108, 2016. https://doi.org/10.1016/j.rse.2015.12.042

JET PROPULSION LABORATORY. Intelligent Payload Experiment (IPEX). Available at: https://www.jpl.nasa.gov/cubesat/missions/ipex.php. Access: Sep. 2019.

JIANG, E. et al. Potentiality of Using Luojia 1-01 Nighttime Light Imagery to Investigate Artificial Light Pollution. Sensors, v. 18, n. 9, 2018. https://doi.org/10.3390/s18092900

KÄ̈̈B, A.; ALTENA, B.; MASCARO, J. River ice and water velocities using the Planet optical cubesat constellation. Hydrology and Earth System Sciences, v. 23, n. 10, p. 4233 4247, 2019. https://doi.org/10.5194/hess-23-4233-2019

KAMECHE, M.; BENBOUZID, A. B.; BENZENIAR, H.; AMRI, R. Disaster Monitoring Constellation Using Nanosatellites. Journal of Aerospace Technology and Management, v. 6, n.1, p.93-100, 2019. https://doi.org/10.5028/jatm.v6i1.281

KARTEN SPACE. Satellite Geo-Intelligence For Business. 2019. Available at: https://kartenspace.com/\#parallax_header. Access: Sep. 2019.

JORGE, D. S. F.; BARBOSA, C. C. F.; CARVALHO, L. A. S.; AFFONSO, A. G.; LOBO, F. L.; NOVO, E. M. L. SNR (Signal-To-Noise Ratio) Impact on Water Constituent Retrieval from Simulated Images of Optically Complex Amazon Lakes. Remote Sensing, v. 9, n. 7, p. 644, 2017. https://doi.org/10.3390/rs9070644

LANDSAT ADVISORY GROUP. Recommendations for Possible Future U.S. Global Land Data Collection Missions Beyond Landsat 9. Reston, 2018.

LI, C.; ZOU, L.; WU, Y.; XU, H. Potentiality of Using Luojia1-01 Night-Time Light Imagery to Estimate Urban Community Housing Price-A Case Study in Wuhan, China. Sensors, v. 19, n. 14, 2019. https://doi.org/10.3390/s19143167

LI, X.; LIU, Z.; CHEN, X.; SUN, J. Assessing the Ability of Luojia 1-01 Imagery to Detect Feeble Nighttime Lights. Sensors, v. 19, n. 17, 2019. https://doi.org/10.3390/s19173708 
LI, X.; ZHAO, L.; LI, D.; XU, H. Mapping Urban Extent Using Luojia 1-01 Nighttime Light Imagery. Sensors, v. 18, n. 8, 2018. https://doi.org/10.3390/s18113665

LIU, H.; DAHLGREN, R. A.; LARSEN, R. E.; DEVINE, S. M.; ROCHE, L. M.; GEEN, A. T.; WONG, A. J. Y.; COVELLO, S.; JIN, Y. Estimating Rangeland Forage Production Using Remote Sensing Data from a Small Unmanned Aerial System (sUAS) and PlanetScope Satellite. Remote Sensing, v. 11, n. 5, p. 1-22, 2019. https://doi.org/10.3390/rs11050595

MA, L.; XIE, P.; LIU, D.; WU, Y. Research on the Influence of China's Commercial Spaceflight on the Economic and Social Development of the Regions Along the Belt and Road. Mary Ann Liebert, v. 7, n. 4, 2019. https://doi.org/10.1089/space.2019.0012

MACIEL, D.; NOVO, E.; BARBOSA, C.; MARTINS, V.; FLORES JÚNIOR, R.; OLIVEIRA, A.; SANDER DE CARVALHO, L.; LOBO, F. Evaluating the potential of CubeSats for Remote Sensing Reflectance Retrieval over inland waters. International Journal of Remote Sensing and Remote Sensing Letters, v. 41, n. 7, 2020. https://doi.org/10.1080/2150704X.2019.1697003

MARTINS, V. S.; NOVO, E. M. L. M.; LYAPUSTIN, A.; ARAGÃO, L. E. O. C.; FREITAS, S. R.; BARBOSA, C. C. F. Seasonal and interannual assessment of cloud cover and atmospheric constituents across the Amazon (2000-2015): Insights for remote sensing and climate analysis. ISPRS Journal of Photogrammetry and Remote Sensing, v. 145, p. 309-327, 2018. https://doi.org/10.1016/j.isprsjprs.2018.05.013

MCCABE, M. F.; ARAGON, B.; HOUBORG, R.; MASCARO, J. CubeSats in Hydrology: Ultrahigh-Resolution Insights into Vegetation Dynamics and Terrestrial Evaporation. Water Resources Research, v. 53, p. 10017-10024, $2017 \mathrm{a}$. https://doi.org/10.1002/2017WR022240

MCCABE, M. F.; RODELL, M.; ALSDORF, D. F.; MIRALLES, F. G.; UIJLENHOET, R.; WAGNER, W.; LUCIEER, A.; HOUBORG, R.; VERHOEST, N. E. C.; FRANZ, T. E.; SHI, J.; GAO, H.; WOOD, E. F. The future of Earth observation in hydrology. Hydrology and Earth System Sciences, v. 21, n. 7, p. 3879-3914, $2017 \mathrm{~b}$. https://dx.doi.org/10.5194\%2Fhess-21-3879-2017

MHANGARA, P.; MAPURISA, W.; MADAU, N. Image Interpretability of nSight-1 Nanosatellite Imagery for Remote Sensing Applications. Aerospace, v. 7, n. 19, 2020. https://doi.org/10.3390/aerospace7020019

NANOSATS AND CUBESATS DATABASE. Nanosats Database. 2019. Available at: https://www.nanosats.eu/database. Access: Sep. 2019.

OVERSTREET, B. T.; LEGLEITER, C. J. Removing sun glint from optical remote sensing images of shallow rivers. Earth Surface Processes and Landforms, v. 42, p. 318-333, 2016. https://doi.org/10.1002/esp.4063

PANDEY, B.; JOSHI, P. K.; SETO, K. C. Monitoring urbanization dynamics in India using DMSP/OLS night time lights and SPOT-VGT data. International Journal of Applied Earth Observation, v. 23, p. 49-61, 2013. https://doi.org/10.1016/j.jag.2012.11.005

PARK, S. H.; JUNG, H. S.; LEE, M. J.; LEE, W. J.; CHOI, M. J. Oil Spill Detection from PlanetScope Satellite Image: Application to Oil Spill Accident near Ras Al Zour Area, Kuwait in August 2017. Journal of coastal Research, v. 90, p. 251-260, 2019. https://www.jstor.org/stable/26778961 
PATERSON, R. R. M.; LIMA, N. How will climate change affect mycotoxins in food? Food $\begin{array}{llllllll}\text { research international, } & \text { v. } 43, \quad \text { n. } 7, \quad \text { p. } 1902-1914,\end{array}$ https://doi.org/10.1016/j.foodres.2009.07.010

PIRO, A.; CASELLA, D.; CIOLO, L. D.; PINORI, S.; CAPPELLETI, C.; BATTISTINI, S.; GRAZIANI, F. HYBRIS: Analysis and Design of a Hyper-Spectral CubeSat Mission for Multiple Remote Sensing Applications and Earth Observation Synergies. In: SYMPOSIUM, 4, 2018, Sorrento. Proceedings[...] Sorrento: ESA, 2018.

PLANET TEAM. Planet Application Program Interface: In Space for Life on Earth. San Francisco, 2017. https://api.planet.com

POURSANIDIS, D.; TRAGANOS, D.; CHRYSOULAKIS, N.; REINARTZ, P. Cubesats Allow High Spatiotemporal Estimates of Satellite-Derived Bathymetry. Remote Sensing, v. 11, n. 11, 2019. https://doi.org/10.3390/rs11111299

RABIONET, M. C. Study of future perspectives of micro/nanosatellites constellations in the Earth Observation market. 2019. 94f. Dissertação (Master's Degree in Aeronautical Engineering) - Universitat Politécnica de Catalunya, Barcelona, 2019.

REAKTOR SPACE LAB. Reaktor Hello World. 2019. Available at: https://reaktorspace.com/reaktor-hello-world/. Access: Sep. 2019.SANDAU, R. Status and Trends of Small Satellite Missions for Earth Observation. Acta Astronautica, v. 66, n. 1-2, p. 1-12, 2010. https://doi.org/10.1016/j.actaastro.2009.06.008

SANDAU, R.; BRIE, K.; ERRICO, M. D. Small Satellites for Global Coverage: Potential and Limits. ISPRS Journal of Photogrammetry and Remote Sensing, v. 65, n. 6, p. $492-$ 503, 2010. https://doi.org/10.1016/j.isprsjprs.2010.09.003

SANTILli, G.; VENDITTOZI, C.; CAPPELlETTI, C.; BATTISTINI, S.; GESSINI, P. CubeSat Constellations for Disaster Management in Remote Áreas. Acta Astronautica, v. 145, p. 11-17, 2018. https://doi.org/10.1016/j.actaastro.2017.12.050

SATREVOLUTION. Real-Time Earth-Observation Constellation. 2019. Available at: https://satrevolution.com/rec/. Access: Sep. 2019.

SHENDRYK, Y.; RIST, Y.; TICEHURST, C.; THORBURN, P. Deep learning for multi-modal classification of cloud, shadow and land cover scenes in PlanetScope and Sentinel-2 imagery. IPRS Journal of Photogrammetry and Remote Sensing, v. 157, p. 124-136, 2019. https://doi.org/10.1016/j.isprsjprs.2019.08.018

SHI, Y.; YE, H.; RUAN, C. XING, N.; GENG, Y.; DONG, Y.; PENG, D. Partial Least Square Discriminant Analysis Based on Normalized Two-Stage Vegetation Indices for Mapping Damage from Rice Diseases Using PlanetScope Datasets. Sensors, v. 18. n. 6, p. 1-16, 2019. https://doi.org/10.3390/s18061901

SHIROMA, W. A.; MARTIN, L. K.; AKAGI, J. M.; AKAGI, J. T.; WOLFE, B. L.; FEWELL, B. A.; OHTA, A. T. CubeSats: A Bright Future for Nanosatellites. Central European Journal of Engineering, v. 1, n. 1, p. 9-15, 2011. https://doi.org/10.2478/s13531-0110007-8 SURREY SATELLITE TECHNOLOGY. SSTL-CUBE. 2019. Available at: https://www.sstl.co.uk/. Access: Sep. 2019.

SWARTWOUT, M. The first One Hundred CubeSats: A Statistical Look. Journal of Small Satellites, v. 2, n. 2, p. 213-233, 2013. 
TEKEVER. Innovation Projects. 2019. Available at: https://www.tekever.com/projects/. Access: Sep. 2019.

VANHELLEMONT, Q. Daily metre-scale mapping of water turbidity using CubeSat imagery. Optics Express, v. 27, n. 20, 2019. https://doi.org/10.1364/OE.27.0A1372

VILLELA, T.; COSTA, C. A.; BRANDÃO, A. M.; BUENO, F. T.; LEONARDI, R. Towards the Thousandth CubeSat: A Statistical Overview. International Journal of Aerospace Engineering, v. 2019, p. 1-13, 2019. https://doi.org/10.1155/2019/5063145

XUAN, M. Analysis of China's Nano and Microsatellite Industry Development. Aerospace China, v. 20, n. 1, 2019.

XUE, Y.; LI, Y.; GUANG, J.; ZHANG, X.; GUO, J. Small Satellite Remote Sensing and Applications - History, Current and Future. International Journal of Remote Sensing, v. 29, n. 15, p. 4339-4372, 2008. https://doi.org/10.1080/01431160801914945

ZHANG, X. C.; LIU, W. Z. Simulating potential response of hydrology, soil erosion, and crop productivity to climate change in Changwu tableland region on the Loess Plateau of China. Agricultural and Forest Meteorology, v. 131, n. 3-4, p. 127-142, 2005. https://doi.org/10.1016/j.agrformet.2005.05.005

ZHANG, G.; LI, L.; JIANG, Y.; SHEN, X.; LI, D. On-Orbit Relative Radiometric Calibration of the Night-Time Sensor of the LuoJia1-01 Satellite. Sensors, v. 18, n. 12, 2018a. https://doi.org/10.3390/s18124225

ZHANG, G.; GUO, X.; LI, D.; JIANG, B. Evaluating the Potential of LJ1-01 Nighttime Light Data for Modeling Socio-Economic Parameters. Sensors, v. 19, n. 6, 2019. https://doi.org/10.3390/s19061465

ZHANG, Z.; XU, G.; SONG, J. CubeSat cloud detection based on JPEG2000 compression and deep learning. Advances in Mechanical Engineering, v. 10, n. 10, 2018b. https://doi.org/10.1177\%2F1687814018808178

WICAKSONO, P.; LAZUARDI, W. Assessment of PlanetScope images for benthic habitat and seagrass species mapping in a complex optically shallow water environment. International Journal of Remote Sensing, v. 39, n. 17, 2018. https://doi.org/10.1080/01431161.2018.1506951

WU, S.; ZHAO, T.; GAO, Y.; CHENG, X. Design and Implementation of a Cube Satellite Mission for Antarctic Glacier and Sea Ice Observation. Acta Astronautica, v. 139, p. 313-320, 2017. https://doi.org/10.1016/j.actaastro.2017.07.023

WOLDAI, T. The status of Earth Observation (EO) \& GeoInformation Sciences in Africa trends and challenges. Geo-spatial Information Science, v. 23, n. 1, 2020. https://doi.org/10.1080/10095020.2020.1730711 